\title{
Histological abnormalities in biopsies from macroscopically normal colonoscopies
}

\author{
I R SANDERSON, S BOYLE, C B WILLIAMS, AND J A WALKER-SMITH \\ Departments of Child Health and Histopathology, St Bartholomew's Hospital, London
}

SUMmARY One hundred and nineteen children with gastrointestinal symptoms underwent colonoscopy during the course of one year. Out of 39 children that were reported as yielding normal results on endoscopic examination, six had disease detectable only by histology. The pathology included cases of microscopic colitis, Crohn's disease, and indeterminate colitis. To exclude large bowel inflammation as a cause of gastrointestinal symptoms biopsy specimens should always be taken at endoscopy.

Colonoscopy is now used as an important diagnostic technique in paediatric gastroenterology. It may even be used safely in infants. It is performed using sedation and not under general anaesthesia. ${ }^{1-4}$ Multiple biopsy specimens can be taken at the time of colonoscopy. In adult practice a group of patients with chronic watery diarrhoea have been described who, in the presence of normal endoscopic appearances, have an infiltration of excess chronic inflammatory cells in the colonic mucosa. ${ }^{5}$ The aim of this paper is to report the histological findings in biopsy specimens taken from a series of children with normal appearance at endoscopy and so to determine whether biopsy specimens are necessary to evaluate the mucosa when the endoscopic appearances are normal.

\section{Methods and materials}

Children with symptoms suggesting chronic inflammatory bowel disease who underwent colonoscopy at St Bartholomew's Hospital and the Queen Elizabeth Hospital for Children, London, between September 1983 and September 1984 were entered into the study. The macroscopic appearances were reported at the time of the procedure. Children whose colonoscopy was reported as showing a normal vascular pattern throughout were selected. Biopsy specimens were taken from the caecum, transverse colon, sigmoid colon, and rectum for fixation in formal saline. They were embedded in paraffin, sectioned at $5 \mu$, and stained with haematoxylin and eosin. Each case was reported by one pathologist and independently reviewed by another (SB).
Stools were cultured in every child for pathogenic bacteria and examined for ova, cysts, and parasites. Serology was taken to detect yersiniosis or amoebiasis. Tuberculosis was tested by Mantoux test and chest $x$ ray film. ${ }^{\circ}$ The small bowel was investigated by barium follow through and, when appropriate, by proximal small bowel biopsy. Barium enema, which yields no more information than colonoscopy, ${ }^{7}$ was not performed.

\section{Results}

One hundred and nineteen children underwent colonoscopy between September 1983 and September 1984. Of these, 39 had a normal endoscopic appearance. Biopsy specimens from six of these were histologically abnormal.

The clinical features of these children (Table 1) are those commonly seen in a paediatric gastroenterology practice. Four children had profuse diarrhoea, which in one case was associated with rectal prolapse. Four weighed less than the third centile for their age. The three oldest children complained of abdominal pain.

Histological findings. The histological abnormalities found in the six children are given in Table 2.

Three patients (cases 1, 2, and 3) had severe diffuse inflammation in the lamina propria (Fig. 1) with degeneration of the surface epithelium. Increased numbers of lymphocytes, plasma cells, histiocytes, and eosinophil polymorphs were found in the lamina propria. Intraepithelial neutrophils, crypt abscesses, and mild distortion of the glands 
Table 1 Clinical features and diagnosis in six children with normal appearances at endoscopy

\begin{tabular}{|c|c|c|c|c|c|}
\hline $\begin{array}{l}\text { Case } \\
\text { No }\end{array}$ & $\begin{array}{l}\text { Age } \\
\text { (years) }\end{array}$ & Sex & Symptoms & $\begin{array}{l}\text { Diagnosis of colonic } \\
\text { discease }\end{array}$ & Other diagnosis \\
\hline 1 & 1 & $\mathbf{M}$ & Diarrhoca: failure to thrive & Indeterminate colitis & Autoimmune enteropathy \\
\hline 3 & 6 & $\mathbf{F}$ & Diarrhoea: weight loss & Indeterminate colitis & $\begin{array}{l}\text { (1) Probable coeliac disease } \\
\text { (2) Thyrotoxicosis }\end{array}$ \\
\hline 4 & 8 & $\mathbf{M}$ & Ahdominal pain: diarrhoca & Indeterminate colitis & \\
\hline 6 & 14 & $\mathrm{~F}$ & Abdominal pain & Crohn's disease & \\
\hline
\end{tabular}

Table 2 Histological features of the colonic biopsies

\begin{tabular}{|c|c|c|c|c|c|}
\hline $\begin{array}{l}\text { Case } \\
\text { No }\end{array}$ & $\begin{array}{l}\text { Mucosal } \\
\text { inflammation }\end{array}$ & $\begin{array}{l}\text { Intraepithelial } \\
\text { polymorphs }\end{array}$ & $\begin{array}{l}\text { Crypt } \\
\text { abscesses }\end{array}$ & Crypt architecture & Other features \\
\hline 1 & Moderate & + & + & $\begin{array}{l}\text { Gland distortion, dilatation. } \\
\text { and branching }\end{array}$ & $\begin{array}{l}\text { Goblet cell depletion: } \\
\text { thin surface epithelium }\end{array}$ \\
\hline 2 & Heavy & + & + & $\begin{array}{l}\text { Minor gland distortion } \\
\text { and branching }\end{array}$ & Goblet cell depletion \\
\hline 3 & Heavy with cosinophils & + & - & Normal & $\begin{array}{l}\text { Goblet cell depletion: } \\
\text { thin surface epithelium }\end{array}$ \\
\hline 5 & Mild and patchy & - & - & Minor gland distortion & \\
\hline 6 & Mild and patchy & - & - & Minor gland distortion & Non-caseating granulomas \\
\hline
\end{tabular}

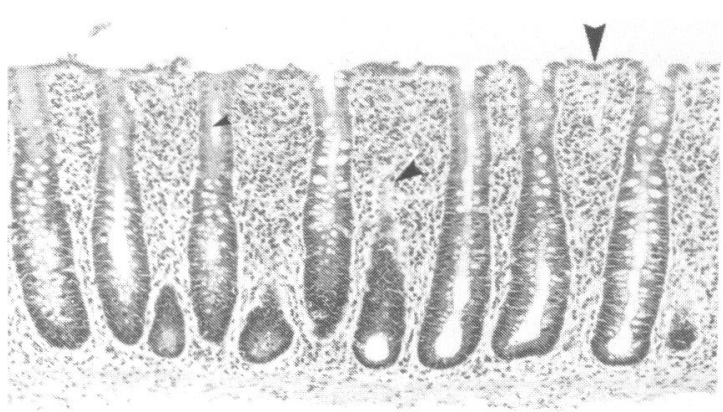

Fig. 1 Case 3-Colonic biopsy specimen showing severe diffuse inflammation of the lamina propria (medium sized arrow), goblet cell depletion (small arrow), and attenuation of the surface epithelium (large arrow). Haematoxylin and eosin. Original magnification $\times 125$.

with goblet cell depletion were present in cases 1 and 2 (Fig. 2).

In two patients (cases 4 and 5) there was patchy mild chronic inflammation in the lamina propria (Fig. 3). The inflammatory cells consisted of lymphocytes, plasma cells, histiocytes, and eosinophil polymorphs. There was minor gland distortion with a normal goblet cell population. No granulomas were seen.

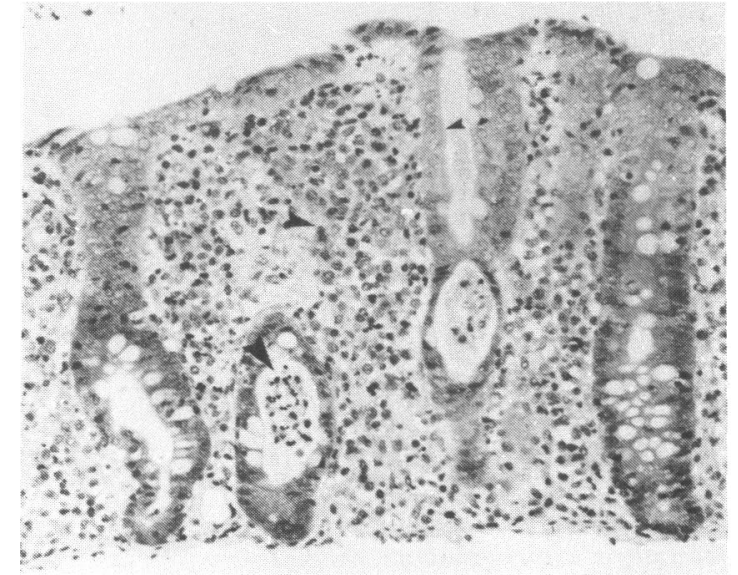

Fig. 2 Case 1-Colonic biopsy specimen showing severe diffuse inflammation of the lamina propria (medium sized arrow) with gland distortion, crypt abscesses (large arrow), and goblet cell depletion (small arrow). Haematoxylin and eosin. Original magnification $\times 270$.

In another patient (case 6) whose biopsy specimen showed mild and patchy inflammation, noncaseating, epithelioid granulomas were present in the lamina propria (Fig. 4). 


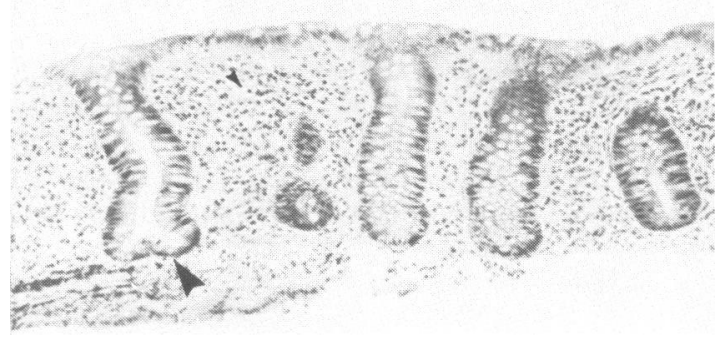

Fig. 3 Case 4-Colonic biopsy specimen showing mild chronic inflammation of the lamina propria (small arrow) and mild distortion and branching of the glands (large arrow). Haematoxylin and eosin. Original magnification $\times 125$.

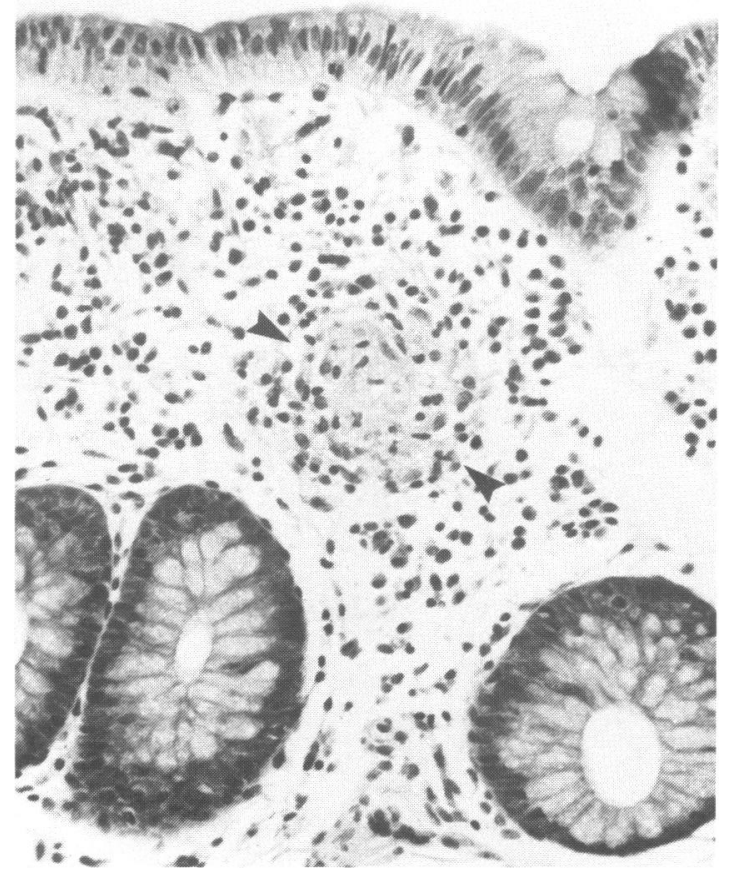

Fig. 4 Case 6-A non-caseating epithelioid granuloma (arrows) in the lamina propria of the colon. Haematoxylin and eosin. Original magnification $\times 325$.
Children with abnormal small bowel morphology $\cdot \frac{\rho}{?}$ Four of the six patients had abnormal proximal small bowel biopsy specimens (Table 3).

Subtotal villous atrophy with crypt hyperplasia $\stackrel{\overline{\mathcal{O}}}{+}$ was reported in case 1 . This child was still an infant드 and had never ingested gluten. He gained weight $\frac{\bar{O}}{\bar{n}}$ only on parenteral nutrition. Serology showed an $\frac{\bar{\rho}}{\vec{D}}$ autoantibody to small intestinal epithelial cells.

In two patients (cases 2 and 5) the jejunal biopsy specimen showed subtotal villous atrophy consistent $\overrightarrow{0}$ with untreated coeliac disease. Both responded to $a^{\circ}$ gluten free diet. Stool culture from case 2 showed a $\vec{\omega}$ growth of Campylobacter jejuni.

The small bowel biopsy specimen of case $3 \frac{0}{2}$ showed a severe partial villous atrophy with crypt $\frac{?}{\sigma}$ hyperplasia. The child had, however, been on a strict gluten free diet for five years as a small bowel biopsy performed during infancy had shown severe villous atrophy. She initially responded to the removal of gluten from her diet but despite strict adherence to the diet deteriorated three years later. $\vec{z}$ She also developed thyrotoxicosis at this time.

Diagnoses. In one child the inflammation in the $\vec{\varphi}$ colon was due to Crohn's disease. The remaining. five patients had an indeterminate colitis. ${ }^{8}$

Case 1 had an autoimmune enteropathy. Antiepithelial cell antibodies have been detected in other $\bar{\partial}$ children" ${ }^{10}$ and found to cause small bowel disease. The colonic inflammation found in this child is $\frac{2}{\mathbb{Q}}$ probably also of autoimmune aetiology.

In cases 2 and 5 a provisional diagnosis of $\overrightarrow{\overline{0}}$ untreated coeliac disease was made from the jejunal $\frac{3}{\sqrt{3}}$ biopsy specimen, the presence of an antigliadin antibody, and the response to a gluten free diet. The inflammation in the colon in case 2 could have been $\frac{0}{0}$ due to the campylobacter infection.

Case 3 fulfils the diagnostic criteria of microscopic $\frac{\sigma}{3}$ colitis. "11 Firstly, histology of the large bowel showed diffuse inflammation; and, secondly, no $\frac{0}{3}$ cause was found for the chronic diarrhoea that 0 continued after the child's thyrotoxicosis had been treated and after the small bowel morphology had $\frac{D}{2}$ returned to normal with treatment with steroids.

Table 3 Results of small bowel biopsies in four of the six cases

\begin{tabular}{|c|c|c|c|c|c|}
\hline $\begin{array}{l}\text { Case } \\
\text { No }\end{array}$ & lilli & crypts & Lamina propria & $\begin{array}{l}\text { Intraepithelial } \\
\text { lymphocytes }\end{array}$ & Other features \\
\hline 1 & Suhtotal villous atrophy & Hyperplastic & $\begin{array}{l}\text { Excess plasma cells: } \\
\text { cosinophils }\end{array}$ & Normal & Anti-epithelial cell antibody \\
\hline 2 & Subtotal villous atrophy & Hyperplastic & Excess plasma cells & Raised & Positive antigliadin antibody \\
\hline 3 & Severe villous atrophy & Hyperplastic & $\begin{array}{l}\text { Excess macrophages: } \\
\text { cosinophils: plasma } \\
\text { cells: lymphocytes }\end{array}$ & Raised & \\
\hline
\end{tabular}


The colitis found in case 4 was mild. He was the brother of a child with Crohn's colitis, but no diagnostic features of this condition were found. Case 6 had Crohn's disease.

\section{Discussion}

In six out of 119 children $(5 \%)$ undergoing colonoscopy, disease was only found after histological examination. It has never previously been shown that total colonoscopy may fail to detect inflammation in children, although it is well known that in conditions causing visible patchy inflammation, such as Crohn's disease, inflammatory cells and even granulomas may be found in areas that appear normal. In performing colonoscopy it is important. therefore, not only to examine the whole colon but also to take biopsy specimens in all cases.

Although all six children had colonic disease detectable only on histological examination, the causes of the disease were diverse. Only one case completely fulfilled the criteria for microscopic colitis drawn up by Kingham et al that the inflammation be uniform and without identifiable cause..$^{5}$

Three of the six cases described by Kingham had abnormal small bowel biopsy specimens. In our series a colitis was present in two children with probable coeliac disease. (A definite diagnosis of coeliac disease cannot be made until a formal gluten challenge has been performed to satisfy the criteria of the European Society for Paediatric Gastroenterology and Nutrition. ${ }^{12}$ ) Although in one child the inflammation could be attributed to an intercurrent infection with campylobacter, the other had no evidence of bacterial or viral infection. The question arises whether large bowel enteropathy can occur as a consequence of coeliac disease. No prospective study of large bowel disease in coeliac disease has been performed. ${ }^{13}$ In adults,${ }^{14}$ however, inflammation of the large bowel, evident on endoscopy, has been reported to occur more often than the respective prevalences of coeliac disease and inflammatory bowel disease would predict. Colonic inflammation severe enough to cause rectal bleeding has also been described in two children with coeliac disease. ${ }^{15}$ Nevertheless. microscopic large bowel inflammation is not an invariable finding in children with coeliac disease as children with active coeliac disease in this unit have undergone colonoscopy and multiple biopsy without showing disease.

Kingham et al described one case of microscopic colitis occurring in a 56 year old woman who had responded to a gluten free diet five years previously..$^{5}$ Case 3 in our series similarly developed a microscopic colitis on a gluten free diet. The relation between coeliac disease and microscopic colitis, however, remains unclear.

In conclusion, it is essential to take biopsy specimens at colonoscopy, even when normal, if the causes of gastrointestinal symptoms in childhood are to be found. The results of histology, however, do not all fit a diagnosis of microscopic colitis but display varied disease.

I R Sanderson is supported by the Crohn's in Childhood Research Appeal. The authors are grateful to Professor G Slavin for his encouragement and to Mrs D O'Keefe for photographic help.

\section{References}

1 Cadranel S, Rodesch P, Peeter JP, Cremer M. Fibcrendoscopy of the gastrointestinal tract in children. Am J Dis Child 1977;131:41-5.

2 Williams CB. Laage NJ. Campbell CA, et ai. Total colonoscopy in children. Arch Dis Child 1982:57:49-53.

Hassall E. Barclay GN, Ament ME. Colonoscopy in childhood. Pediatrics 1984:73:594-9.

${ }^{4}$ Howdle PD, Littlewood JM. Firth J, Losowsky MS. Routine colonoscopy service. Arch Dis Child 1984:59:790-3.

5 Kingham JGC, Levison DA. Ball JA, Dawson AM. Microscopic colitis-a cause of chronic watery diarrhoea. $\mathrm{Br}$ Med $\mathrm{J}$ 1982;285:1()61-4.

' Chong SKF, Bartram CI, Camphell CA, Williams CB, Blackshaw AJ, Walker-Smith JA. Chronic inflammatory bowel diseasc in childhood. $\mathrm{Br}$ Med $J$ 1982:284:101-3.

7 Elliott PR, Lennard-Jones JE, Bartram Cl, et al. Colonoscopic diagnosis of minimal change colitis in patients with a normal sigmoidoscopy and normal air contrast barium enema. Lancet 1982:i:650-1

${ }^{*}$ Chong SKF, Blackshaw AJ, Boyle S, Williams CB, WalkerSmith JA. Histological diagnosis of chronic inflammatory bowel disease in childhood. Gut 1985:26:69-74.

${ }^{9}$ Unsworth J, Hutchins P, Mitchell J, et al. Flat small intestinal mucosa and autoantibodies against the gut epithelium. J Pediatr Gastroenterol Nutr 1982;1:503-523.

10 Savage MO. Mirakian R, Wozniak ER, et al. Specific autoantibodies to gut epithelium in two infants with severe protracted diarrhoca. J Pediatr Gastroenterol Nutr 1985;4:187-195.

$"$ Bo-Linn GW, Vendrell DD, Lec E, Fortran JS. An evaluation of the significance of microscopic colitis in patients with chronic diarrhoea. J Clin Invest 1985:75:1559-69.

12 Mceuwissc GW. Diagnostic criteria in coeliac disease. Acta Paediatr Scand 1970;59:461-3.

13 Cooke WT, Holmes GKT, eds. Coeliac disease. Edinburgh: Churchill Livingston, 1984.

${ }^{14}$ Kitis G, Holmes GFT, Cooper BT. Thompson H, Allan RN. Association of cocliac disease and inflammatory bowel disease. Gut 1980:636-41.

15 Ansaldi N, Santini B, Dell Otis D, Levis F. Proctosigmoiditis and cocliac discase. Arch Dis Child 1978;53:645-8.

Correspondence to Dr I R Sanderson, Department of Child Health, St Bartholomew's Hospital, London EC1A 7BE.

Received 6 December 1985 